\title{
Antioxidant Properties and Toxicity Assessment of the Crescentia cujete Extracts in Brine Shrimp (Artemia salina)
}

(Sifat Antioksidan dan Ketoksikan Penilaian ekstrak Crescentia cujete pada Udang Air Garam (Artemia salina)

\author{
MOZHIARHASI SANDRA SAgRIN, NUR FATIMAH LASANO, RADHIAH SHUKRI \& NURUL SHAZINI RAMLI*
}

\begin{abstract}
Crescentia cujete has traditionally been used to treat various ailments. The present study attempted to determine the antioxidant activities of $100 \%$ ethanol, $50 \%$ ethanol and aqueous extracts of the leaves, bark and fruit of the herb. Additionally, the toxicity of the extracts was investigated in brine shrimp. The results showed that 100\% ethanol leaf extract had the highest antioxidant activity with an $I_{50}$ value of $261.97 \pm 0.57 \mu \mathrm{g} / \mathrm{mL}$ according to the 2,2-diphenyl-1picrylhydrazil (DPPH) radical scavenging assay. Estimation of the total phenolic content (TPC) using the Folin-Ciocalteu reagent showed that the leaves extracted with $100 \%$ ethanol had the highest concentration of TPC compared to the extracts prepared with other solvents of all parts of the plant. Analysis of the minerals using inductively coupled plasma atomic emission spectroscopy (ICP-OES) showed that the parts of the plant primarily consist of high levels of phosphorus, magnesium and calcium. Titration analysis of vitamin $C$ showed that the highest concentration of the vitamin is present in the bark. High performance liquid chromatography (HPLC) analysis of vitamin E indicated that the content is the highest in the fruit, and the content of vitamin A was the highest in the leaves. Brine shrimp lethality assay (BSLA) results showed that $50 \%$ ethanol extract of the leaves is the most toxic during a $24 \mathrm{~h}$ treatment. Thus, the leaves and bark exhibit excellent antioxidant effects and can be potentially developed as functional food ingredients. The findings of the present study suggest further research in cell lines and in vivo.
\end{abstract}

Keywords: Calabash; minerals; polyphenol; toxicity; vitamins

ABSTRAK

Crescentia cujete telah digunakan secara tradisi untuk merawat pelbagai penyakit. Kajian ini bertujuan untuk menentukan aktiviti antioksida terhadap 100\% etanol, 50\% etanol dan akues ekstrak daun, kulit kayu dan buah. Di samping itu, penilaian ketoksikan ekstrak ke atas udang brin juga dikaji. Keputusan menunjukkan daun yang diekstrak dengan $100 \%$ etanol mempunyai aktiviti antioksida yang paling tinggi dengan nilai $I_{50} 261.97 \pm 0.57 \mu \mathrm{g} / \mathrm{mL}$, diuji menggunakan ujian esei radikal 2,2-diphenil-1-picrylhidrazil (DPPH). Penilaian jumlah kandungan fenolik (TPC) menggunakan reagen Folin-Ciocalteau menunjukkan bahawa daun yang diekstrak menggunakan 100\% etanol mempunyai kepekatan tertinggi berbanding dengan ekstrak bahagian tumbuhan lain yang disediakan dengan pelarut lain. Analisis mineral menggunakan spektrometer pancaran optik-plasma gandingan aruhan (ICP-OES) menunjukkan bahawa semua bahagian tumbuhan yang telah diuji mengandungi fosforus, magnesium dan kalsium yang tinggi. Titrasi vitamin C telah menunjukkan kandungan tertinggi dalam kulit. Selain itu, analisa kromatografi cecair berprestasi tinggi (HPLC) vitamin E menunjukkan kandungan tertinggi dalam buah sementara vitamin A adalah paling tinggi dalam daun. Keputusan analisis kemautan udang brin (BSLA) menunjukkan bahawa ekstrak daun dengan menggunakan etanol 50\% adalah yang paling toksik semasa pengujian selama 24 jam. Kajian ini dengan jelas menunjukkan bahawa daun, kulit dan buah Crescentia cujete adalah toksik dan bioaktif. Oleh itu, daun dan kulit mengandungi antioksida dan berpotensi untuk dibangunkan sebagai bahan makanan fungsian. Keputusan kajian ini mencadangkan kajian lanjut dalam lapisan sel dan in vivo.

Kata kunci: Ketoksikan; labu kayu; mineral; polifenol; vitamin

\section{INTRODUCTION}

Reactive oxygen species (ROS) are chemically reactive molecules containing oxygen that are mainly produced by the mitochondrial electron transport chain (ETC) as by-products of the common cellular metabolism (He et al. 2017). ROS are small but highly reactive. Ros play important roles in such cellular functions as communication and homeostasis; however, at elevated levels, ROS may harm human health (Gorlach et al. 2015). The balance of
ROS in the body is commonly regulated by the antioxidant capacity of a cell. Interference that alters this balanced state results in a pro-oxidant state known as oxidative stress. Oxidative stress can cause a number of negative effects in the human body especially due to chemical reactions of ROS with the lipids and proteins due to the highly reactive nature of Ros (Gorlach et al. 2015). Some of the negative effects include cardiovascular diseases, cancer, neurodegeneration, diabetes, and ageing, cataract 
(Morell 2008; Ohta 2012; Poljsak et al. 2013). Therefore, maintenance the normal cellular ROS concentration is critical to ensure the regulation of normal physiological functions throughout the body. However, the formation of these reactive species can be counteracted by consuming sufficient amounts of exogenous antioxidants (Poljsak et al. 2013).

An antioxidant is any substance that delays, prevents and inhibits oxidative damage to the target molecules. Antioxidants can repair the injuries caused by oxidative stress by acting as free radical scavengers, inhibiting the initiation or propagation of the oxidative chain reactions and quenching the singlet oxygen (Xu et al. 2017). The main sources of exogenous antioxidants include food and medicinal plants, such as spices, fruits and vegetables $(\mathrm{Xu}$ et al. 2017). The natural compounds from these sources are rich in vitamins (A, C and E), minerals (selenium) and carotenoids, such as $\beta$-carotene, lycopene, lutein and polyphenols (lignans, phenolic acids, anthocyanins, flavonoids and stilbenes). These compounds have proven antioxidant activities that help to strengthen the mechanisms of the defence against damage caused by 'oxidative stress' (Wasek et al. 2014; Xu et al. 2017). Natural antioxidants have been the main choice for consumers due to toxicological reasons because synthetic antioxidants may lead to a number of health hazards (Taghvaei \& Jafari 2015). Therefore, numerous studies are focusing on the search, characterization and application of natural antioxidants.

Crescentia cujete is called 'labu kayu' by local population in Malaysia. This herb is one of the thousands of plants that were traditionally used to heal numerous ailments. The parts of the plant, especially fruit, leaves and bark, are usually boiled in water or alcohol before being used to treat diseases. Several studies had supported the traditional application of the parts of this plant and proved that various parts of the Crescentia cujete tree possess numerous health benefits, such as anti-inflammatory, antibacterial, DPPH radical scavenging, antioxidant, cytotoxic, antivenom, central nervous system depressant and wound healing activities (Dawodu et al. 2016). Moreover, Das et al. (2014) has reported that the leaves of this plant have high potential for development as a natural antioxidant. However, there are lack of studies using ethanol extracts which are excellent for the extraction of antioxidant polyphenols. Therefore, a comprehensive study of the efficacy of the water and ethanolic extracts in scavenging free radicals and of the toxicity level of the extracts should be performed. The results will deliver ample information related to the benefits and safety of the extracts in domestic consumption. Development of this plant as one of the potent natural antioxidant sources can be can be considered an expansion of the medical, nutraceutical and functional food industry. Additionally, determining the lethal concentration of the extracts may provide a proper guidance for safe consumption of the parts of this plant.

\section{MATERIALS AND METHODS}

\section{SAMPLES}

Fresh leaves, bark and fruit of Crescentia cujete were harvested from the garden trees at Sitiawan, Perak, Malaysia. The plant materials were ensured to be free of physical and microbial damage. The identification of the samples was conducted by a botanist from Institute of Bioscience, Universiti Putra Malaysia. The specimen voucher number is SK 3136/17.

\section{MATERIALS}

Ethanol, 2,2-diphenyl-1-picrylhydrazyl (DPPH), FolinCiocalteau phenol reagent, gallic acid, anhydrous sodium carbonate and 2,6-indophenol standard solution were purchased from Merck (Darmstadt, Germany). Potassium dichromate, ascorbic acid, metaphosphoric acid, anhydrous sodium sulphate, $\alpha$-tocopherol standard solution, $\beta$-carotene standard solution, acetic acid, acetone, ethyl acetate, hexane, hydrochloric acid, methanol, nitric acid, petroleum ether, phenolphthalein, potassium hydroxide, sodium chloride and sodium hydroxide were of analytical and HPLC grades and were obtained from Sigma-Aldrich (New York, USA).

\section{SAMPLE PREPARATION}

The method was adapted from Vuthijumnok et al. (2013) with some modifications; the deep freezing temperature was decreased from $-20^{\circ} \mathrm{C}$ to $-80^{\circ} \mathrm{C}$. All the plant materials were initially cleaned under running tap water and the pulps were cut into cubes $(2 \times 2 \times 2) \mathrm{cm}^{3}$. The cut fruits were immediately packed into a plastic zip lock bag to prevent oxidation and were deep frozen at $-80^{\circ} \mathrm{C} \pm 1^{\circ} \mathrm{C}$ for at least $24 \mathrm{~h}$. The deep-frozen samples were then freeze-dried at $-50^{\circ} \mathrm{C}$ for at least 3 days until they were completely dry using a freeze-dryer (LABANCO, Labanco Corporation, Kansas City, Missouri, USA) at $0.120 \mathrm{mBar}$. The freezedried samples were then blended using a blender (HR 2001, Philips, Selangor, Malaysia) and sieved to obtain a fine powder. The samples were kept at $4^{\circ} \mathrm{C}$ in an air tight container until further analysis.

\section{SAMPLE EXTRACTION}

The extraction method was adapted from Huda-Faujan et al. (2015) with some modifications; the ratio of the samples to the solvents was increased from 1:7 (w/v) to $1: 10(\mathrm{w} / \mathrm{v})$. The solvents $(50 \%$ ethanol, $100 \%$ ethanol and $100 \%$ distilled water) were added into the samples at the ratio of 1:10 (w/v) and the mixtures were stored in the dark condition for $72 \mathrm{~h}$. Then, the extracts were filtered using a Buchner funnel through a Whatman No. 1 filter paper and the residual solvent was evaporated using a rotary evaporator (N-100, Eyela, Tokyo, Japan) with an aspirator (A-1000S, Eyela, Tokyo, Japan) at $75^{\circ} \mathrm{C}$ and $50 \mathrm{rpm}$ rotation. The crude extracts obtained were then 
weighed. The yield percentage was calculated using the following equation:

$$
\% \text { Yield }=\frac{\mathrm{W}_{2}-\mathrm{W}_{1}}{\mathrm{~W}_{0}} \times 100,
$$

where $\mathrm{W}_{2}$ is the weight of the extract and the container; $\mathrm{W}_{1}$ is the weight of the container alone; and $\mathrm{W}_{0}$ is the weight of the freeze-dried sample.

\section{DETERMINATION OF THE TOTAL PHENOLIC CONTENT}

This method was adapted from Singleton and Rossi (1965) with some modifications; the extracts were dissolved using the corresponding extraction solvents instead of using methanol. Standard gallic acid solutions (3.125 ppm-100 ppm) were prepared to construct a standard calibration curve. Folin-Ciocalteau reagent $(2.5 \mathrm{~mL}$ of $10 \%)$ and $2 \mathrm{~mL}$ of $7.5 \%$ sodium were added into $0.5 \mathrm{~mL}$ of plant extract. The mixtures were vortexed using a vortex (LMS-1003, Genius 3, Gyeonggi-do, KOREA) for $10 \mathrm{~s}$ and incubated in an incubation oven (100-800, Memmert, Schwabach, German) at $40^{\circ} \mathrm{C}$ for $1 \mathrm{~h}$ in the dark. The absorbance was measured at $756 \mathrm{~nm}$ using a spectrophotometer (UV-1650PC, Shimadzu, Kyoto, Japan). The results were expressed as $\mu \mathrm{g} \mathrm{GAE} / \mathrm{g}$ extract.

\section{DPPH RADICAL SCAVENGING ACTIVITY}

The method was adapted from Jing et al. (2015) with some modifications; the concentration of DPPH solution was increased from $100 \mu \mathrm{M}$ to $500 \mu \mathrm{M}$ and the absorbance was measured at $515 \mathrm{~nm}$ instead of $517 \mathrm{~nm}$. The samples (31.25 $\mu \mathrm{g} / \mathrm{mL}-500 \mu \mathrm{g} / \mathrm{mL}$ ) or positive control (ascorbic acid) methanol solution $(100 \mu \mathrm{L})$ were added to $100 \mu \mathrm{L}$ of 500 $\mu \mathrm{M}$ DPPH methanol solutions $(5.9 \mathrm{mg} / 100 \mathrm{~mL}$ methanol) in a 96-well microplate. The remaining DPPH radicals were determined by the absorbance at $515 \mathrm{~nm}$ using a microplate reader (EL800, BioTek, Vermont, USA) after incubation at room temperature for $30 \mathrm{~min}$. Scavenging activities were determined by the following equation:

$$
\% \text { of inhibition }=\frac{\left({ }^{\mathrm{A}} \text { control }-{ }^{\mathrm{A}} \text { sample }\right)}{\mathrm{A}_{\text {control }}} \times 100 \text {. }
$$

The $\mathrm{IC}_{50}$ value obtained by extrapolation using linear regression analysis corresponds to the concentration of the sample required to scavenge $50 \%$ of the DPPH radicals.

\section{MINERAL ANALYSIS}

Fresh leaves, fruit and bark were used for mineral analysis. The sample $(0.1 \mathrm{~g})$ was weighed into a vessel. Then, $10 \mathrm{~mL}$ of $\mathrm{HNO}_{3}$ and $5 \mathrm{~mL}$ of $\mathrm{HCl}$ were added into a vessel. The vessel was placed into a microwave digester for $1 \mathrm{~h}$. After $1 \mathrm{~h}$, the sample was cooled, and the volume was adjusted to $45 \mathrm{~mL}$ with $1 \% \mathrm{HNO}_{3}$. The samples were analysed using an ICP-OES system (5300 DV, Perkin Elmer, Massachusetts,
USA). Calculations were performed according to the following equation:

$$
\% \text { Element }=\frac{\text { Reading from ICP-OES } \times \text { Dilution } \times \text { Volume }(\mathrm{mL})}{\text { Weight of test material in } \mathrm{g} \times 10000} \times 100 \text {, }
$$

\section{DETERMINATION OF ANTIOXIDANT VITAMINS}

\section{VITAMIN A}

The method was adapted from AOAC Official Method (AOAC 2005). Eighty millilitres of $95 \%$ ethanol was added to a flask containing $20 \mathrm{~g}$ samples followed by $20 \mathrm{~mL}$ of $20 \%$ potassium hydroxide and a few boiling chips. Then, the flask was attached to a water-cooled refluxing apparatus, and the samples were heated with refluxing for $30 \mathrm{~min}$. After that step, the unit was cooled down to room temperature. Then, the hydrolysates were extracted three times with $50 \mathrm{~mL}$ of hexane. The hexane extracts were combined and washed with distilled water until the solution was neutral according to phenolphthalein. The hexane extracts were filter-washed using anhydrous sodium sulphate. The volumes of the extracts were reduced using a rotary evaporator. The residues were immediately re-dissolved in $5 \mathrm{~mL}$ mobile phase (methanol) and transferred to a $10 \mathrm{~mL}$ volumetric flask. The volume was adjusted to the mark with the mobile phase. The extracts were filtered using a $0.45 \mu \mathrm{m}$ membrane filter (PTFE). Twenty microliters of the extract was injected into an HPLC system (2695 \& 996, Waters Alliance, California, USA) for analysis. Beta-carotene was used as the standard solution. Vitamin A content was calculated according to the following equation:

$$
\beta \text {-carotene, } \mathrm{ppm}=\frac{\mathrm{C} \times 10}{\mathrm{Ws}}
$$

where $\mathrm{C}$ is the concentration according to the standard curve (ppm); and Ws is the sample weight $(\mathrm{g})$.

\section{VITAMIN C}

The method was adapted from AOAC Official Method (AOAC 1990). Fresh samples were used for this analysis. Freshly prepared ascorbic acid solution was used as the standard. Approximately $10 \mathrm{~g}$ of the sample and metaphosphoric acid-acetic acid solution were added into a conical flask, and the volume was adjusted to 200 $\mathrm{mL}$. Then, the filtrates were titrated with standardized indophenol reagent until pink colour remained for at least $5 \mathrm{~s}$, and the results are expressed as mg ascorbic acid per $100 \mathrm{~g}$ sample according to the following equation:

$$
\mathrm{mg} \text { ascorbic acid per } 100 \mathrm{~g} \text { sample }=\mathrm{X} \times \mathrm{A} \times \frac{\mathrm{V}}{\mathrm{Y}} \times \frac{100}{\mathrm{~W}}
$$

where $\mathrm{X}$ is the volume of indophenol used to titrate the sample $(\mathrm{mL})$; $\mathrm{A}$ is the volume of indophenol used to titrate the ascorbic acid standard (equivalent to $\mathrm{mg}$ of ascorbic acid present in the sample) $(\mathrm{mL}) ; \mathrm{V}$ is the total volume 
$(\mathrm{mL})$ of the test sample; $\mathrm{Y}$ is the total volume $(\mathrm{mL})$ of the sample used in titration to pink colour $(10 \mathrm{~mL})$; and $\mathrm{W}$ is the weight of the sample $(\mathrm{g})$.

\section{VITAMIN E}

The method was adapted from AOAC Official Method (AOAC 1990). Ten grams of the sample, $50 \mathrm{~mL}$ of $95 \%$ ethanol, $50 \%$ potassium hydroxide and $0.25 \mathrm{~g}$ of ascorbic acid were added into a $250 \mathrm{~mL}$ boiling flask. The flask was then attached to a water-cooled reflux apparatus. After 30 min heating, the unit was cooled to room temperature. Then, the solutions were transferred into a separating funnel, and the flask was rinsed with $50 \mathrm{~mL}$ distilled water. The extraction was performed using $25 \mathrm{~mL}$ petroleum ether with vigorous shaking. The upper layer contained the petroleum ether extract and was collected by removing the lower layer into a beaker. The extraction step was repeated twice by adding $25 \mathrm{~mL}$ of ether. Finally, the ether extracts were combined and washed with distilled water until the solution was neutral according to phenolphthalein. Then, the extracts were filter-washed using anhydrous sodium sulphate and evaporated using nitrogen gas. The extracts were diluted with methanol and filtered through a $0.45 \mu \mathrm{m}$ membrane filter (PTFE). Ten microliters of the extract were injected into an HPLC system (385-LC, Varian, Shropshire, UK) for analysis. Vitamin E ( $\alpha$-tocopherol) was used as the standard solution, and the samples were spiked with $0.5 \mu \mathrm{L}$ of the stock standard solution. The column was reversed-phase C18 (5 $\mu \mathrm{m} ; 4.6 \times 150 \mathrm{~mm} \mathrm{ID)}$ attached to a fluorescence detector with excitation wavelength of 296 $\mathrm{nm}$ and emission wavelength of $330 \mathrm{~nm}$. Flow rate was 1.0 $\mathrm{mL} / \mathrm{min}$ using the gradient pump mode. Vitamin $\mathrm{E}$ content was calculated according to the following equation:

$$
\text { Vitamin } \mathrm{E}, \mathrm{mg} / \mathrm{kg}=\frac{\mathrm{C} \times 10}{\mathrm{Ws}}
$$

where, $\mathrm{C}$ is the concentration according to the standard curve (ppm); and Ws is the sample weight $(\mathrm{g})$.

\section{BRINE SHRIMP LETHALITY TEST}

The method was adapted from Syahmi et al. (2010) with some modifications; the extracts were dissolved using the corresponding extraction solvents instead of methanol and petri dishes were used for $24 \mathrm{~h}$ treatment instead of bijoux bottles. Brine shrimp eggs, Artemia salina was hatched and used to test the potential toxicity of the samples' crude extracts. By referring to the Meyer's toxicity index, the crude extracts with $\mathrm{LC}_{50}<1000 \mu \mathrm{g} / \mathrm{mL}$ were considered toxic, and the crude extracts with $\mathrm{LC}_{50}>1000 \mu \mathrm{g} / \mathrm{mL}$ were considered non-toxic (Hamidi et al. 2014).

\section{ARTEMIA SALINA LETHALITY ASSAY}

The sample extracts were dissolved using the corresponding extraction solvents and diluted with artificial seawater (3.8\% $\mathrm{NaCl}$ solution). The sample extracts were serially diluted with artificial seawater $(1.953 \mu \mathrm{g} / \mathrm{mL}-1000 \mu \mathrm{g} / \mathrm{mL})$. Twenty millilitres of the solution of each concentration was transferred into a corresponding Petri dish and incubated for $24 \mathrm{~h}$. After that step, potassium dichromate $\left(\mathrm{K}_{2} \mathrm{Cr}_{2} \mathrm{O}_{7}\right)$ was dissolved in artificial seawater, and the solution was used as a positive control with concentrations of 1000 , $500,250,125,62.5,31.25,15.625,7.813,3.907$, and 1.953 $\mu \mathrm{g} / \mathrm{mL}$. Negative control was prepared using ethanol and distilled water. The Petri dishes were observed, and the dead larvae from each Petri dish were counted after $24 \mathrm{~h}$. Based on the mortality percentage, the concentration that caused $50 \%$ lethality $\left(\mathrm{LC}_{50}\right)$ of the nauplii was determined by using the plot of the mean mortality percentage versus the log of concentration.

$$
\begin{aligned}
& \begin{array}{l}
\text { Percentage of } \\
\text { death }(\%)
\end{array}: \begin{array}{l}
(\% \text { Death in the test plate })- \\
(\% \text { Death in the control plate })
\end{array} \times 100 \% \\
& 100-\% \text { Death in the test plate }
\end{aligned}
$$

\section{STATISTICAL ANALYSIS}

The results are expressed as the mean of the triplicates \pm standard deviation. Significant difference was set at the 95\% confidence level. All analyses were conducted by Tukey's test using the Minitab 16 software.

\section{RESULTS AND DISCUSSION}

\section{CONTENTS OF MINERALS AND ANTIOXIDANT VITAMINS IN C. cujete}

The mineral and vitamin contents in different parts of C. cujete are presented in Table 1 . The bark contains the highest level of sodium, phosphorus, zinc and copper followed by the leaves and fruit. Conversely, the leaves had the highest amount of calcium, magnesium, manganese, iron and selenium. This finding is consistent with the data of Ejelonu et al. (2001), who reported the very low levels of calcium and magnesium in the fruit $(4 \mathrm{mg} / 100 \mathrm{~g}$ and $0.01 \mu \mathrm{g} / \mathrm{mL}$, respectively). Similarly, Olusi et al. (2015) found exceptionally high levels of calcium, phosphorus, magnesium and iron in the bark $(2267.24 \mathrm{mg} / 100 \mathrm{~g}$, $56.64 \mathrm{mg} / 100 \mathrm{~g}, 216.65 \mathrm{mg} / 100 \mathrm{~g}$ and $89.84 \mathrm{mg} / 100 \mathrm{~g}$, respectively). However, in contrast to the earlier findings, low levels of manganese and sodium were found in the bark of $C$. cujete at $4.36 \mathrm{mg} / 100 \mathrm{~g}$ and $0.07 \mathrm{mg} / 100$ $\mathrm{g}$, respectively (Olusi et al. 2015). The recommended nutrient intake (RNI) for healthy adult Malaysian men and women 19-50 year of age is $1000 \mathrm{mg}$ per day (MOH 2017). Therefore, $C$. cujete leaves may provide for the daily calcium needs by consumption of less than 300 g leaves. Certain nutrients serve as antioxidants or are the components of the antioxidant enzymes, such as selenium, copper, zinc, manganese and iron. Deficiency of these elements causes oxidative stress and damage to the biological molecules and membranes which will occur when these elements are not consumed in sufficient amount (McDowell et al. 2007). In general, the leaves, bark and fruit of $C$. cujete had different composition of the nutrients, 
and the nutrient contents are significantly $(p<0.05)$ higher in the leaves. The distribution and allocation of the nutrients in the leaves, bark and fruit indicate the capacity of the plants to obtain, transport and store the nutrients (Zhang et al. 2015). However, the mineral distribution in the parts of a plant may vary because of climate, soil composition or nutrient level, harvest time, genotypes, preparation method and maturity level (San et al. 2009).

Vitamin analysis showed that the fruit contains the highest amount of vitamin $\mathrm{E}$; the bark had the highest level of vitamin $\mathrm{C}$; and the leaves contain the highest amount of vitamin A. Vitamin $\mathrm{E}$ is a fat-soluble vitamin well known for its high antioxidant potency (Ye et al. 2013). The vitamin E contents in $C$. cujete were relatively low in all parts of the plant $(p<0.05)$. Additionally, the amount of vitamin $C$ is significantly $(p<0.05)$ different between the parts of the plant. However, when the vitamin $\mathrm{C}$ levels were compared in a study of Ogunlesi et al. (2010), it was demonstrated that the vitamin C contents in C. cujete were lower than that in the tropical vegetables. In their study, the samples identified as rich in vitamin $\mathrm{C}$ included red pepper $(123.73 \mathrm{mg} / 100 \mathrm{~g})$ and curry plant $(140.50 \mathrm{mg} / 100$ $\mathrm{g}$ ). The recommended nutrient intake (RNI) of vitamin $\mathrm{C}$ for healthy Malaysian men and women are $70 \mathrm{mg}$ per day (MOH 2017). C. cujete contains relatively low amount of vitamin $\mathrm{C}$ considering the daily human needs because a larger serving is required. Vitamin $\mathrm{A}$ is best known for its excellent antioxidant properties and is the best quencher of the singlet oxygen (Fiedor \& Burda 2014). C. cujete contains a reasonable amount of vitamin $\mathrm{A}$ in the leaves $(22.94 \pm 0.32 \mathrm{mg} / 100 \mathrm{~g})$, bark $(14.47 \pm 0.08 \mathrm{mg} / 100 \mathrm{~g})$ and fruit $(0.15 \pm 0.00 \mathrm{mg} / 100 \mathrm{~g})(p<0.05)$. In this study, the amount of vitamin A was higher than that in other studies. Igwenyi and Elekwa (2014) reported the vitamin A content in a traditional herb, Geranium robertianum, of $1.44 \pm$ $0.02 \mathrm{mg} / 100 \mathrm{~g}$; therefore, the herb can be a good source of vitamin A. Hence, the leaves and bark of $C$. cujete can serve as an excellent source of vitamin A.

\section{QUANTIFICATION OF TOTAL PHENOLIC AND ANTIOXIDANT ACTIVITY}

The fruit, leaves and bark of $C$. cujete were freeze-dried and extracted using $100 \%$ ethanol, $50 \%$ ethanol and water (aqueous). Ethanol and water are less toxic and safer than other solvents, such as hexane, acetone and methanol (Chew et al. 2011). Table 2 presents the extraction yield, total phenolic content and the $\mathrm{IC}_{50}$ values of the fruit, leaf and bark extracts of $C$. cujete. The results indicate that the extraction yield is the highest in the fruit followed by the leaves and bark $(p<0.05)$. Additionally, the results showed that water is the most effective solvent for extraction of the compounds from the C. cujete fruit, whereas $50 \%$ ethanol is the most effective solvent for extraction of the compounds from the $C$. cujete leaves and bark. A possible explanation for this may be that the fruit is

TABLE 1. Content of minerals and vitamins in fruit, leaves and bark of Crescentia cujete

\begin{tabular}{|c|c|c|c|c|c|}
\hline \multicolumn{4}{|c|}{ Content } & \multirow{2}{*}{$\begin{array}{c}\text { Adult RNI } \\
\text { (man, woman)* }\end{array}$} & \multirow{2}{*}{$\begin{array}{c}\text { Adult DRIs } \\
\text { (man, woman)\# }\end{array}$} \\
\hline & Fruit & Leaves & Bark & & \\
\hline \multicolumn{6}{|l|}{ Mineral } \\
\hline Sodium (mg/100 g) & $9.03 \pm 2.75^{b}$ & $8.03 \pm 0.89^{\mathrm{b}}$ & $18.20 \pm 0.62^{\mathrm{a}}$ & $(1500,1500) \mathrm{mg} / \mathrm{d}$ & $(2300,2300) \mathrm{mg} / \mathrm{d}$ \\
\hline Phosphorus (mg/100 g) & $40.36 \pm 5.32^{\mathrm{b}}$ & $38.64 \pm 2.90^{\mathrm{b}}$ & $60.53 \pm 0.12^{\mathrm{a}}$ & $(700,700) \mathrm{mg} / \mathrm{d}$ & $(580,580) \mathrm{mg} / \mathrm{d}$ \\
\hline Calcium (mg/100 g) & $4.50 \pm 1.13^{c}$ & $474.24 \pm 32.19^{a}$ & $268.84 \pm 12.42^{\mathrm{b}}$ & $\begin{array}{l}(1000,1000 \text { for } 19-50 ; 1200 \\
\text { for } 51-59 \mathrm{y}) \mathrm{mg} / \mathrm{d}\end{array}$ & $(1000,1000) \mathrm{mg} / \mathrm{d}$ \\
\hline Magnesium (mg/100 g) & $19.79 \pm 2.68^{c}$ & $75.10 \pm 6.10^{\mathrm{a}}$ & $45.39 \pm 0.55^{b}$ & $\begin{array}{l}(420,310 \text { for } 19-29 y ; 320 \text { for } \\
30-50 y ; 420 \text { for } 51-59 y) \mathrm{mg} / \mathrm{d}\end{array}$ & $(420,320) \mathrm{mg} / \mathrm{d}$ \\
\hline Manganese (mg/100 g) & $0.09 \pm 0.02^{\mathrm{c}}$ & $0.61 \pm 0.04^{\mathrm{a}}$ & $0.25 \pm 0.03^{b}$ & $(2.3,1.8) \mathrm{mg} / \mathrm{d}$ & $(2.3,1.8) \mathrm{mg} / \mathrm{d}$ \\
\hline Iron $(\mathrm{mg} / 100 \mathrm{~g})$ & $0.29 \pm 0.11^{\mathrm{c}}$ & $1.56 \pm 0.12^{\mathrm{a}}$ & $0.78 \pm 0.11^{\mathrm{b}}$ & $\begin{array}{c}(14,29 \text { for } 19-50 \mathrm{y} ; 11 \text { for } \\
51-59) \mathrm{mg} / \mathrm{d}\end{array}$ & $(45,45) \mathrm{mg} / \mathrm{d}$ \\
\hline Copper $(\mu \mathrm{g} / 100 \mathrm{~g})$ & $200.00 \pm 0.04^{\mathrm{b}}$ & $310.00 \pm 0.04^{\mathrm{b}}$ & $560.00 \pm 0.10^{\mathrm{a}}$ & $(900,900) \mu \mathrm{g} / \mathrm{d}$ & $(10,000,10,000) \mu \mathrm{g} / \mathrm{d}$ \\
\hline Zinc (mg/100 g) & $0.37 \pm 0.09^{\mathrm{b}}$ & $0.57 \pm 0.01^{\mathrm{a}}$ & $0.61 \pm 0.10^{\mathrm{a}}$ & $\begin{array}{c}(6.5,4.7 \text { for } 19-29 \mathrm{y} ; 4.6 \text { for } \\
30-59) \mathrm{mg} / \mathrm{d}\end{array}$ & $(9.4,6.8) \mathrm{mg} / \mathrm{d}$ \\
\hline Selenium $(\mu \mathrm{g} / 100 \mathrm{~g})$ & $1.13 \pm 0.00^{\mathrm{c}}$ & $13.72 \pm 0.01^{\mathrm{a}}$ & $5.87 \pm 0.00^{\mathrm{b}}$ & $(32,24) \mu \mathrm{g} / \mathrm{d}$ & $(45,45) \mu \mathrm{g} / \mathrm{d}$ \\
\hline \multicolumn{6}{|l|}{ Vitamin } \\
\hline Vit. A (mg/100g) & $0.15 \pm 0.00^{c}$ & $22.94 \pm 0.32^{\mathrm{a}}$ & $14.47 \pm 0.08^{\mathrm{b}}$ & $(600,600) \mu \mathrm{g} / \mathrm{d}$ & $(500,550) \mu \mathrm{g} / \mathrm{d}$ \\
\hline Vit. C (mg/100g) & $5.76 \pm 0.78^{c}$ & $7.95 \pm 0.05^{\mathrm{b}}$ & $9.32 \pm 0.00^{\mathrm{a}}$ & $(70,70) \mathrm{mg} / \mathrm{d}$ & $(60,70) \mathrm{mg} / \mathrm{d}$ \\
\hline Vit. E (mg/100g) & $0.02 \pm 0.00^{\mathrm{a}}$ & $0.003 \pm 0.00^{\mathrm{b}}$ & $0.002 \pm 0.00^{\mathrm{c}}$ & $(10,7.5) \mathrm{mg} / \mathrm{d}$ & $(12,12) \mathrm{mg} / \mathrm{d}$ \\
\hline
\end{tabular}

Small letters indicate significant $(p<0.05)$ differences of means between the different plant parts. They are expressed in mean $\pm \mathrm{SD}(n=3)$. RNI $=\mathrm{Recommended} \mathrm{Nutrient}$ Intake for Malaysia. DRI = Daily Reference Intake. *Values are based on people aged 19-59 years from Ministry of Health Malaysia (2017). \#Values are based on people aged 19-70 years from National Institute of Health (2015) 
composed of highly water-soluble molecules, including proteins and carbohydrates. Therefore, high polarity of water compared to other solvents explains greater ability of water to extract the polar compounds from the samples (Delfanian et al. 2015). However, water cannot extract the compounds with high number of the carbon bonds. Hence, mixing ethanol and water at a suitable extraction coefficient may assist with the extraction of the compounds with high number of the carbon bonds (Delfanian et al. 2015). The results obtained in the leaves and bark support this hypothesis. These two parts of the plant may have compounds with higher number of the carbon bonds.

Total phenolic content of $C$. cujete was quantified using the Folin-Ciocalteu assay. The concentration of TPC was expressed as gallic acid equivalent (GAE)/g extract. The results showed that the highest concentration of TPC was observed in the leaves extracted using $100 \%$ ethanol $(1281.10 \pm 0.33 \mu \mathrm{g} \mathrm{GAE} / \mathrm{g}$ extract $)$. Comparison of the parts of the plant indicates that $100 \%$ ethanol extracted the highest amount of TPC compared with that in the case of water and $50 \%$ ethanol. Overall, the contents decrease in the following order: leaves $(100 \%$ ethanol) $>$ leaves (aqueous) $>$ leaves $(50 \%$ ethanol $)>$ bark $(100 \%$ ethanol $)>$ fruit $(100 \%$ ethanol $)>$ bark $(50 \%$ ethanol $)>$ bark (aqueous) $>$ fruit $(50 \%$ ethanol) $>$ fruit (aqueous). Das et al. (2014) evaluated the total phenolic content of the extracted $C$. cujete bark and leaves in crude ethanol extract, chloroform fraction, ethyl acetate fraction and water fraction. The ethanolic extract had the highest concentration of TPC compared to that in the aqueous extract of the leaves and bark in agreement with the results obtained in this study. However, the concentration of TPC was significantly higher compared to that obtained in this study. Differences in results obtained in the same species can be attributed to differences in plant origin, procedures and standards used to assess the TPC content (Huda-Faujan et al. 2015). The results of our study indicate that the leaves contain the highest TPC levels followed by the bark and fruit $(p<0.05)$ (Table 2$)$. This finding is most likely due to relatively higher abundance of unbound low molecular weight polar phenolic compounds in the leaves compared to that in the bark and fruit (Ghazi et al. 2012; Russo et al. 2013). Moreover, bark and fruit usually contain high levels of structural polysaccharides that bind high proportion of polyphenols thus masking their detection in the assay of phenolic compounds (PerezJimenez \& Saura-Calixto 2005).

The radical scavenging properties of $C$. cujete fruit, bark and leaves were evaluated using the DPPH assay. This assay has high reproducibility and sensitivity (Buenger et al. 2006). DPPH radical scavenging activities of $100 \%$ ethanol, $50 \%$ ethanol and aqueous extracts of the fruit, leaves and bark of $C$. cujete were tabulated and compared. Figure 1 shows that each part of the plant has variable scavenging activities depending on the solvent used for extraction. The results indicate that different solvents have different polarity, dispersibility and penetration thus resulting in selective extraction of various phytochemicals (Zhang 2015). Thus, the solvents used for extraction will affect the extraction efficiency of the target compounds and influence the scavenging activities of the extracts. The $\mathrm{IC}_{50}$ values of the extracts were calculated and the results are shown in Table 2. Lower $\mathrm{IC}_{50}$ values indicate

TABLE 2. Extraction yield, total phenolic content and $\mathrm{IC}_{50}$ values of fruit, leaves and bark extracts of Crescentia cujete

\begin{tabular}{lccc}
\hline Sample & $\begin{array}{c}\text { Extraction yield } \\
(\%)\end{array}$ & $\begin{array}{c}\text { Total Phenolic } \\
(\mathrm{mg} \mathrm{GAE} / 100 \mathrm{~g} \\
\text { extract })\end{array}$ & $\begin{array}{c}\mathrm{IC}_{50} \\
(\mu \mathrm{g} / \mathrm{mL})\end{array}$ \\
\hline Fruit & & & \\
Aqueous & $86.05 \pm 4.24^{\mathrm{a}}$ & $8.56 \pm 1.47^{\mathrm{c}}$ & $\mathrm{ND}$ \\
$50 \%$ Ethanol & $75.87 \pm 2.18^{\mathrm{a}}$ & $16.34 \pm 0.53^{\mathrm{b}}$ & $\mathrm{ND}$ \\
$100 \%$ Ethanol & $16.69 \pm 0.43^{\mathrm{b}}$ & $166.12 \pm 3.81^{\mathrm{a}}$ & $\mathrm{ND}$ \\
Leaves & & & \\
Aqueous & $10.4 \pm 0.06^{\mathrm{b}}$ & $1215.86 \pm 0.32^{\mathrm{b}}$ & $296.88 \pm 1.77^{\mathrm{b}}$ \\
$50 \%$ Ethanol & $28.29 \pm 0.54^{\mathrm{a}}$ & $672.94 \pm 0.32^{\mathrm{c}}$ & $272.80 \pm 1.48^{\mathrm{c}}$ \\
$100 \%$ Ethanol & $8.12 \pm 0.30^{\mathrm{c}}$ & $1281.10 \pm 0.33^{\mathrm{a}}$ & $261.97 \pm 0.57^{\mathrm{d}}$ \\
Bark & & & \\
& & & $655.83 \pm 16.04$ \\
Aqueous & $8.17 \pm 0.05^{\mathrm{b}}$ & $91.94 \pm 5.79^{\mathrm{c}}$ & $766.53 \pm 14.37$ \\
$50 \%$ Ethanol & $12.54 \pm 0.46^{\mathrm{a}}$ & $146.96 \pm 3.66^{\mathrm{b}}$ & $474.88 \pm 1.35^{\mathrm{a}}$ \\
$100 \%$ Ethanol & $2.75 \pm 0.12^{\mathrm{c}}$ & $278.68 \pm 1.53^{\mathrm{a}}$ & $27.74 \pm 0.03^{\mathrm{e}}$ \\
\hline Ascorbic acid & & & \\
\hline
\end{tabular}

Small letters indicate significant $(p<0.05)$ differences of means between the extracting solvent. They are expressed in mean $\pm \mathrm{SD}(n=3) . \mathrm{IC}_{50}=$ The effective concentration providing $50 \%$ scavenging effect. $\mathrm{ND}=$ not detected. The $\mathrm{IC}_{50}$ value of the fruit extracts unable to be determined within the tested concentration (in the range of $0-3 \mathrm{mg} / \mathrm{mL}$ ) 
lower concentration needed to scavenge $50 \%$ of DPPH free radicals. As shown in Table 2, only leaf and bark extracts had the $\mathrm{IC}_{50}$ within the test concentrations. None of the fruit extracts have achieved the $\mathrm{IC}_{50}$ (Table 2). The strongest radical scavenging was shown by the $C$. cujete leaves extracted using $100 \%$ ethanol.

This finding contradicts the results of Das et al. (2014) who found that aqueous extract of the leaves had lower $\mathrm{IC}_{50}$ values indicating more potent radical scavenging compared to that of the ethanol extract. The contradictions between the results of these studies may be due to a number of factors including differences in the plant matrix and the processing conditions, such as temperature and time of extraction; moreover, all these factors may influence the antioxidant activities (Do et al. 2014). The scavenging activity of $C$. cujete leaf and bark extracts can be influenced by the presence of the compounds that are classified as free radical scavengers, such as flavonoid quercetin, apigenin, naphthoquiones, tannins and steroids (Das et al. 2014). Ethanol is effective in extracting the radical scavengers, such as phenolic compounds, with low and medium molecular weight and medium polarity, including aglycones, flavonoids, anthocyanins, terpenoids, saponins, tannins, totarol, flavones, phenones and polyphenols (Widyawati et al. 2015). These results indicated that the leaves and barks contain the compounds with less polar properties and can be efficiently extracted by ethanol.

\section{TOXICITY ASSESSMENT}

Brine shrimp lethality assay (BSLA) is one of the preliminary cytotoxicity methods based on the ability to kill laboratory-cultured Artemia nauplii. BSLA is an efficient, fast and less expensive assay for testing the bioactivity of the plant extracts. Moreover, a positive correlation between the brine shrimp lethality and oral lethality test in mice had been demonstrated in various studies of medicinal plants (Naidu et al . 2014). The median lethal concentration $\left(\mathrm{LC}_{50}\right)$ of the brine shrimp lethality assay was determined in this study. Median lethal concentration $\left(\mathrm{LC}_{50}\right)$ is the lethal concentration required to kill $50 \%$ of the population after $24 \mathrm{~h}$ of exposure. The $\mathrm{LC}_{50}$ values calculated for
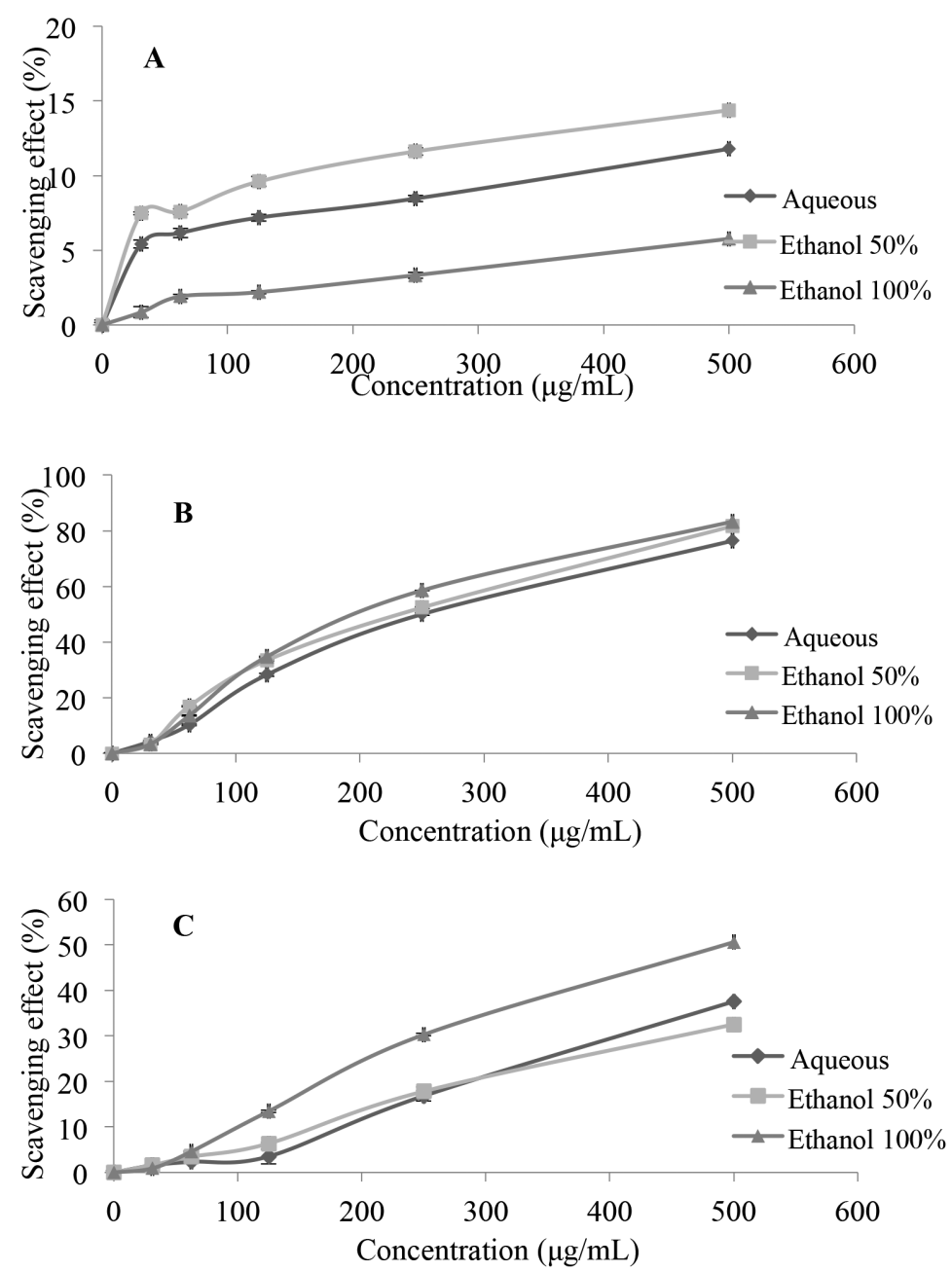

DPPH = 2, 2-diphenyl-1-(2,4,6-trynitrophenyl-hydrazyl)

FIGURE 1. DPPH radical scavenging properties of fruit, leaves and bark extracts of Crescentia cujete:

(A) fruit, (B) leaves and (C) bark 
TABLE $3 . \mathrm{LC}_{50}$ value of ethanolic and aqueous extracts of Crescentia cujete

\begin{tabular}{cccc}
\hline \multicolumn{4}{c}{$\mathrm{LC}_{50}(\mu \mathrm{g} / \mathrm{mL})$} \\
Samples & Fruit & Leaves & Bark \\
\hline Aqueous & $38.74 \pm 1.35^{\mathrm{c}}$ & $5.49 \pm 0.32^{\mathrm{b}}$ & $25.74 \pm 1.35^{\mathrm{a}}$ \\
$50 \%$ Ethanol & $133.15 \pm 4.50^{\mathrm{b}}$ & $4.84 \pm 0.32^{\mathrm{c}}$ & $26.07 \pm 4.50^{\mathrm{a}}$ \\
$100 \%$ Ethanol & $292.17 \pm 0.00^{\mathrm{a}}$ & $11.83 \pm 0.33^{\mathrm{a}}$ & $14.04 \pm 0.00^{\mathrm{b}}$ \\
Potassium Dichromate & & $124.41 \pm 2.08^{\mathrm{c}}$ & \\
(Positive control) & & & \\
\hline
\end{tabular}

Small letters indicate significant differences of means between the extracting solvents. They are expressed in mean $\pm \operatorname{SD}(n=3)$. $\mathrm{LC}_{50}=$ the concentration of the plant extracts and positive control sufficient to obtain $50 \%$ of nauplii mortality of Artemia salina

the ethanolic and aqueous extracts of $C$. cujete are listed in Table 3. Crude extracts with the $\mathrm{LC}_{50}$ values of less than $1000 \mu \mathrm{g} / \mathrm{mL}$ are considered significantly active and toxic while the extracts with the $\mathrm{LC}_{50}$ value of more than $1000 \mu \mathrm{g} / \mathrm{mL}$ are considered non-toxic according to the Meyer's toxicity index The $\mathrm{LC}_{50}$ values of all extracts including potassium dichromate were less than $1000 \mu \mathrm{g} /$ $\mathrm{mL}$. Therefore, all parts of the plant extracted with three types of solvents are bioactive and toxic. Leaves are the most toxic part of $C$. cujete followed by the bark and fruit (Table 3). The bark extracts exhibited the highest toxicity in the case of the $100 \%$ ethanol extract $(14.04 \pm 0.00 \mu \mathrm{g} /$ $\mathrm{mL})$, whereas there is no significant $(p<0.05)$ difference between the $50 \%$ ethanol and aqueous extracts (26.07 $\pm 4.50 \mu \mathrm{g} / \mathrm{mL}$ and $25.74 \pm 1.35 \mu \mathrm{g} / \mathrm{mL}$, respectively). Conversely, the aqueous fruit extracts were the least toxic compared to those of the other parts of the plant followed by $50 \%$ ethanol and $100 \%$ ethanol extracts $(38.74 \pm 1.35$ $\mu \mathrm{g} / \mathrm{mL}, 133.15 \pm 4.50 \mu \mathrm{g} / \mathrm{mL}$ and $292.17 \pm 0.00 \mu \mathrm{g} / \mathrm{mL}$, respectively). The leaf extracts are more bioactive and toxic, apparently due to the high content of the bioactive compounds in the leaves compared to those in the fruit and bark.

The phytochemical screening of the crude ethanol extracts of the $C$. cujete leaves showed the presence of steroids, saponins, alkaloids, tannins, glycosides, terpenes and flavonoids (Das et al. 2014). Conversely, Billacura and Pangcoga (2017) reported that the crude ethanolic and aqueous extracts of $C$. cujete contains trace levels of tannins and alkaloids. These data indicate the reason for low toxicity of the fruit extracts. Hence, at higher levels, the compounds become toxic (Almadin \& Jumawan 2015). Assuming that these leaves are boiled in water in the traditional way of consumption, they can be toxic to the consumers even at lower concentrations. In a study of volatile constituents of the $C$. cujete leaves by Dawodu et al. (2016), toxic agents were not detected within the volatile fraction of the compounds. Therefore, the compounds cannot be lost in the air during boiling and toxicity levels of the leaves should remain the same. However, the findings of the current study do not support the previous studies. Billacura and Laciapaq (2017) and Billacura and Pangcoga (2017) found that the median lethal concentrations of the aqueous and ethanolic extract of the $C$. cujete fruit and leaves are lower compared to those detected in this study. However, the toxicity of the aqueous extracts of $C$. cujete is higher than that of the $100 \%$ ethanolic extracts in agreement with this study. The differences can be due to different preparation methods of the samples; the samples were air dried in the study of Billacura and Pangcoga (2017), whereas the samples were freeze-dried in this study. Furthermore, the differences in the extraction methods can be only one of the factors. The information on the antioxidant activities and the toxicity assessment obtained in the present work provide a rationale for the medicinal use of the plant extracts. A more thorough study of the toxicity of $C$. cujete is recommended to further assess the efficacy and safety of this medicinal species. Better extraction methods with alternative solvents should be explored because this plant can be very beneficial in a number of ways due to the presence of the valuable antioxidant compounds.

\section{CONCLUSION}

The results of the current study indicate that the leaves of the Crescentia cujete plant are rich in minerals and antioxidant vitamins. The extracts of the $C$. cujete plant were able to scavenge free radicals, especially the extracts of the leaves and bark prepared in water or ethanol. However, the beneficial effects may vary depending on the solvent used for the extraction. The leaves extracted with ethanol contain the highest TPC and the lowest TPC was detected in the fruit extracted with water. The parts of the $C$. cujete plant have high potential to be developed as natural antioxidants, especially the leaves. However, all extracts exhibited higher toxicity than potassium dichromate except the ethanolic extract of the fruit. Meyer's toxicity index indicates that $100 \%$ ethanol, $50 \%$ ethanol and aqueous extracts of the plant had high toxicity in brine shrimp Artemia salina. Thus, further studies of the toxicity must be conducted, and concentrations safe for consumption should be determined.

\section{ACKNOWLEDGEMENTS}

The authors wish to thank Universiti Putra Malaysia (UPM) for providing the funding for this research under UPM-Putra Research Grant (Inisiatif Putra Siswazah) (Project No. GP-IPS/2016/9481800). 


\section{REFERENCES}

Almadin, F.J.F. \& Jumawan, J.C. 2015. Preliminary study of the effects of calabash (Crescentia cujete) ethanolic fruit extract to gestating Sprague Dawley rats. International Journal of Technical Research and Applications 19(1): 1-4.

AOAC. 2005. Official Method of Analysis. 18 ed. 5th Rev. Method 971.30. Gaithersburg, Maryland, USA.

AOAC. 1990. Official Methods of Analysis. 15 ed. Gaithersburg, Maryland, USA.

Billacura, M.P. \& Laciapag, G.C.R. 2017. Phytochemical screening, cytotoxicity, antioxidant, and anthelmintic property of the various extracts from Crescentia cujete linn. fruit. Science International Lahore 29(2): 31-35.

Billacura, M.P. \& Pangcoga, K.K.J. 2017. Phytochemical screening, cytotoxicity, mutagenicity, antimutagenicity, and protective potentials of the different solvent extracts from the air-dried leaves of Crescentia cujete Linn. International Journal of Advanced and Applied Sciences 4(4): 118-126.

Buenger, J., Ackermann, H., Jentzsch, A., Mehling, A., Pfitzner, I., Reiffen, K.A., Schroeder, K.R. \& Wollenweber, U. 2006. An interlaboratory comparison of methods used to assess antioxidant potentials 1. International Journal of Cosmetic Science 28(2): 135-146.

Chew, K.K., Ng, S.Y., Thoo, Y.Y., Khoo, M.Z., Wan Aida, W.M. \& Ho, C.W. 2011. Effect of ethanol concentration, extraction time and extraction temperature on the recovery of phenolic compounds and antioxidant capacity of Centella asiatica extracts. International Food Research Journal 18: 571-578.

Das, N., Islam, M.E., Jahan, N., Islam, M.S., Khan, A., Islam, M.R. \& Parvin, M.S. 2014. Antioxidant activities of ethanol extracts and fractions of Crescentia cujete leaves and stem bark and the involvement of phenolic compounds. BMC Complementary and Alternative Medicine 14(1): 45.

Dawodu, O.A., Lawal, O.A., Ogunwande, I.A. \& Giwa, A.A. 2016. Volatile constituents of Crescentia cujete L. American Journal of Essential Oils and Natural Products 4(4): 1-3.

Delfanian, M., Esmaeilzadeh Kenari, R. \& Sahari, M.A. 2015. Influence of extraction techniques on antioxidant properties and bioactive compounds of loquat fruit (Eriobotrya japonica Lindl.) skin and pulp extracts. Food Science \& Nutrition 3(3): 179-187.

Do, Q.D., Angkawijaya, A.E., Tran-Nguyen, P.L., Huynh, L.H., Soetaredjo, F.E., Ismadji, S., \& Ju, Y.H. 2014. Effect of extraction solvent on total phenol content, total flavonoid content, and antioxidant activity of Limnophila aromatica. Journal of Food and Drug Analysis 22(3): 296-302.

Ejelonu, B.C., Lasisi,A.A., Olaremu, A.G. \& Ejelonu, O.C. 2011. The chemical constituents of calabash (Crescentia cujete). African Journal of Biotechnology 10(84): 19631-19636.

Fiedor, J. \& Burda, K. 2014. Potential role of carotenoids as antioxidants in human health and disease. Nutrients 6(2): 466-488

Ghazi, F., Rahmat, A., Yassin, Z., Ramli, N.S. \& Buslima, N.A. 2012. Determination of total polyphenols and nutritional composition of two different types of Ficus carica leaves cultivated in Saudi Arabia. Pakistan Journal of Nutrition 11(11): 1061-1065.

Gorlach, A., Dimova, E.Y., Petry, A., Martinez-Ruiz, A., Hernansanz-Agustin, P., Rolo, A.P., Palmeira, C.M. \& Kietzmann, T. 2015. Reactive oxygen species, nutrition, hypoxia and diseases: Problems solved? Redox Biology 6: 372-385.
Hamidi, M., Jovanova, B. \& Panovska, T. 2014. Toxicological evaluation of the plant products using brine shrimp (Artemia salina L.) model. Macedonian Pharmacy Bulletin 60(1): 9-18.

He, L., He, T., Farrar, S., Ji, L., Liu, T. \& Maa, X. 2017. Antioxidants maintain cellular redox homeostasis by elimination of reactive oxygen species cell. Journal of Physiology and Biochemistry 44: 532-553.

Huda-Faujan, N., Rahim, Z.A., Rehan, M.M. \& Ahmad, F.H. 2015. Comparative analysis of phenolic content and antioxidative activities of eight Malaysian traditional vegetables. Malaysian Journal of Analytical Sciences 19(3): 611-624.

Igwenyi, I.O. \& Elekwa,A.E. 2014. Phytochemical analysis and determination of vitamin contents of Geranium robertianum. Journal of Dental and Medical Sciences 13: 44-47.

Jing, L., Ma, H., Fan, P., Gao, R. \& Jia, Z. 2015. Antioxidant potential, total phenolic and total flavonoid contents of Rhododendron anthopogonoides and its protective effect on hypoxia-induced injury in PC12 cells. BMC Complementary and Alternative Medicine 15: 287.

McDowell, L.R., Wilkinson, N., Madison, R. \& Felix, T. 2007. Vitamins and minerals functioning as antioxidants with supplementation considerations. In Florida Ruminant Nutrition Symposium. Best Western Gateway Grand. Gainesville, FL. pp. 30-31.

Morrell, C.N. 2008. Reactive oxygen species: Finding the right balance. Circulation Research 103: 571-572.

Ministry of Health. 2017. Recommended Nutrient Intakes for Malaysia. Putrajaya, Malaysia.

National Institute of Health. 2015. Nutrient Recommendations: Daily Reference Intakes (DRI). https://ods.od.nih.gov/ Health_Information/Dietary_Reference_Intakes.aspx. Accessed on October 1, 2018.

Naidu, J.R., Ismail, R. \& Sasidharan, S. 2014. Acute oral toxicity and brine shrimp lethality of methanol extract of Mentha spicata L (Lamiaceae). Tropical Journal of Pharmaceutical Research 13(1): 101-107.

Ogunlesi, M., Okiei, W., Azeez, L., Obakachi, V., Osunsanmi, M. \& Nkenchor, G. 2010. Vitamin C contents of tropical vegetables and foods determined by voltammetric and titrimetric methods and their relevance to the medicinal uses of the plants. International Journal of Electrochemical Science 5: 105-115.

Ohta, S. 2012. Molecular hydrogen is a novel antioxidant to efficiently reduce oxidative stress with potential for the improvement of mitochondrial diseases. Biochimica et Biophysica Acta (BBA)-General Subjects 1820(5): 586-594.

Olusi, T.A., Ibukunoluwa, M.R. \& Dada, E.O. 2015. Nutritional quality assessment and antiplasmodial activity of Cajanus cajan (L.) Huth.,Crescentia cujete L. and Myrianthus preussii Engl. from Akure, Southwestern Nigeria. International Journal of Phytomedicine 7(4): 449-458.

Perez-Jimnez, J. \& Saura-Calixto, F. 2005. Literature data may underestimate the actual antioxidant capacity of cereals Journal of Agricultural and Food Chemistry 53(12): 50365040.

Poljsak, B., Suput, D. \& Milisav, I. 2013. Achieving the balance between ROS and antioxidants: When to use the synthetic antioxidants. Oxidative Medicine and Cellular Longevity 2013: 956792.

Russo, D., Kenny, O. \& Smyth, T.J. 2013. Profiling of phytochemicals in tissues from Sclerocarya birrea by HPLC-MS and their link with antioxidant activity. ISRN 
Chromatography. DOI: 10.1155/2013/283462.

San, B., Yildirim, A.N., Polat, M. \& Yildirim, F. 2009. Mineral composition of leaves and fruits of some promising jujube (Zizyphus jujuba Miller) genotypes. Asian Journal of Chemistry 21(4): 2898-2902.

Singleton, V.L. \& Rossi, J.A. 1965. Colorimetry of total phenolics with phosphomolybdic-phosphotungstic acid reagents. American Journal of Enology and Viticulture 16(3): 144-158.

Syahmi, A.R.M., Vijayarathna, S., Sasidharan, S., Latha, L.Y., Kwan, Y.P., Lau, Y.L., Shin, L.N. \& Chen, Y. 2010. Acute oral toxicity and brine shrimp lethality of Elaeis guineensis Jacq. (Oil palm leaf) methanol extract. Molecules 15(11): 8111-8121.

Taghvaei, M. \& Jafari, S.M. 2015. Application and stability of natural antioxidants in edible oils in order to substitute synthetic additives. Journal of Food Science and Technology 52(3): 1272-1282.

Vuthijumnok, J., Molan, A.L. \& Heyes, J.A. 2013. Effect of freeze-drying and extraction solvents on the total phenolic contents, total flavonoids and antioxidant activity of different Rabbiteye blueberry genotypes grown in New Zealand. Journal of Pharmacy and Biological Sciences 8: 42-48.

Wasek, M., Giebu, J., Towicz, M., Sochacka, G. \& Wroczy-Ski, P.I.O.T.R. 2014. The measurement of antioxidant capacity and polyphenol content in selected food supplements. Acta Poloniae Pharmaceutica 72(5): 877-887.

Widyawati, P.S., Budianta, T.D.W., Kusuma, F.A. \& Wijaya, E.L. 2014. Difference of solvent polarity to phytochemical content and antioxidant activity of plu-chea indicia less leaves extracts. International Journal of Pharmacognosy and Phytochemical Research 6(4): 850-855.

Xu, D.P., Li, Y., Meng, X., Zhou, T., Zhou, Y., Zheng, J., Zhang,
J.J. \& Li, H.B. 2017. Natural antioxidants in foods and medicinal plants: Extraction, assessment and resources. International Journal of Molecular Sciences 18(1): 96.

Ye, Y., Li, J. \& Yuan, Z. 2013. Effect of antioxidant vitamin supplementation on cardiovascular outcomes: A metaanalysis of randomized controlled trials. PloS ONE 8(2): e56803.

Zhang, Y.J., Gan, R.Y.,Li, S.,Zhou, Y.,Li,A.N. \& Xu, D.P. 2015. Antioxidant phytochemicals for the prevention and treatment of chronic diseases. Molecules 20: 21138-21156.

Mozhiarhasi Sandra Sagrin, Nur Fatimah Lasano \& Nurul Shazini Ramli*

Department of Food Science

Faculty of Food Science and Technology

Universiti Putra Malaysia

43400 UPM Serdang, Selangor Darul Ehsan

Malaysia

Radhiah Sukri

Department of Food Technology

Faculty of Food Science and Technology

Universiti Putra Malaysia

43400 UPM Serdang, Selangor Darul Ehsan

Malaysia

*Corresponding author; email: shazini@upm.edu.my

Received: 31 July 2018

Accepted: 7 February 2019 